\title{
Creating a Religion: The Emergence and Development of Late Twentieth-Century Asatru
}

When and how exactly did Asatru emerge out of the scattered and heterogenous Romantic, neo-Romantic and völkisch tradition described in the previous chapter? Many Asatruers tell the founding myth of an astonishingly spontaneous and independent appearance of unrelated Germanic Neopagan groups in different countries: Britain, USA, Iceland, Sweden, and Germany - a phenomenon which some interpret as the re-surfacing of archetypal mythic and religious powers.

This apparently spontaneous emergence of Asatru in different countries was fed by two currents related to shifts within Germanic Neopaganism as well as mainstream discourses. Beginning in the 1970s, older völkisch religious groups and ideologies such as German Faith, Ariosophy and Odinism re-grouped and once again recruited a younger membership. At the same time, the growing popularity of Wicca, the New Age, and the esoteric movement in the wake of the hippie era awakened the interest of a broader counter-cultural public in non-Christian religious alternatives. These currents intersected in complex ways. Having had ties to the Western occultist tradition all along, Germanic Neopaganism opened up to new alternative religious ideas. Simultaneously, spiritual counter-cultures harking back to Romantic ideas of survival and revival developed an interest in 'indigenous' cultural and religious traditions. The idea of a faith rooted in pre-Christian Northern Europe did not seem farfetched any longer.

The emergence and development of Asatru since the 1970s can roughly be divided into two periods:1) A period of foundation in the 1970s and 8os, during which the first Asatru groups were formed in Iceland, Sweden, Norway, Britain, and the USA, and the völkisch religious community in Germany started its renewal. It was during this period that the central concerns and controversies that were to become crucial for Asatru's further development were formulated. This period was marked by a gradual shift from racial religions to ethnicist paradigms. 2) A period of establishment and consolidation in the 1990s and 200os, when the controversies of the first period peaked, initiating a process of reformation and adaption to the surrounding societies, their changing perceptions, and their organization of religions. During this period, a-racist Asatru started to gain ground.

(C) KONINKLIJKE BRILL NV, LEIDEN, 2016 | DOI 10.1163/9789004309517_004 


\section{In Search of Religiosity: Germanic Neopaganism 1970-199o}

The continuities between modern Asatru and völkisch religion, as well as the later attempts to become emancipated from this tradition and to reform the movement, can be seen most clearly in the German case. ${ }^{1}$ Here, the renewed interest in the 'Germanic' version of a new Paganism originated in the previously mentioned völkisch and post-war right-wing religious and cultural circles. This milieu's opening up to popular New Age and esoteric currents was initiated by the Armanen-Orden (founded in 1976) and its leaders, Adolf and Sigrun Schleipfer (who later called herself Sigrun von Schlichting). ${ }^{2}$ The two were long-term activists in the völkisch religious and right-wing extremist scene - Adolf in the Guido-von-List-Gesellschaft, Sigrun in the right-wing youth organization Bund Heimattreuer Jugend (Association of Youth True to the Homeland), ${ }^{3}$ and both in the Goden-Orden. The racial-religious ArmanenOrden is a hierarchical nine-level initiatory order. It promotes a racial mysticism inspired by Guido von List's and other Ariosophists' teachings. In the 1980s, it began to include popular Celtic elements, teachings from the emerging goddess movement and feminist spirituality, and elements of a popularized Native American spirituality. With this, and with Sigrun Schleipfer's

1 In the 1980 on and early 9os, I did extensive fieldwork and conducted interviews in the thenactive Asatru milieu, mainly with the Armanen-Orden and related groups. These findings were published in two books (Schnurbein, Religion als Kulturkritik; Göttertrost in Wendezeiten). Unless noted otherwise, the discussion of the emergence of German Germanic Neopaganism is based on these publications and the sources used there.

2 Earlier, she had gone under the names Sigrun Strauß-Hammerbacher, and Sigrun SchleipferFriese. As the daughter of NSDAP-Kreisleiter (district leader) Hans Wilhelm Hammerbacher, she was socialized into the völkisch religious milieu. Hammerbacher authored books and brochures such as Midgards Morgen (Midgard's morning), Die Donar-Eiche. Geschichte eines Heiligtums (The Donar Oak. History of a Sacred Place) or Irminsul. Das germanische Lebensbaumsymbol (Irminsul. The Germanic Symbol of the Life-Tree). Some of his books were sold through the mail order book store which Adolf Schleipfer used to run. Currently, they are re-edited by Orion-Heimreiter Verlag, owned by right-wing publisher Dietmar Munier. Munier was also active in the Bund Heimattreuer Jugend in the 1970s (cf. Felix Krautkrämer, "Wachwechsel in Coburg. Politische Publizistik: Der Verleger Dietmar Munier hat offenbar das Traditionsmagazin 'Nation \& Europa' gekauft," Junge Freiheit 42, no. 09 (2009)). For more on Munier see e.g. Ministry of Interior of Land Schleswig-Holstein, ed. Verfassungsschutzbericht 2008 [Report on the Protection of the Constitution] (Kiel:The Ministry of Interior of Land Schleswig-Holstein, 2008), Stephan Braun and Daniel Hörsch, Rechte Netzwerke - eine Gefahr (Wiesbaden: vs Verlag, 2004).

3 See Jochen Maes, Dokumentation: 'Völkische' Ideologien und Gruppierungen (Berlin: PREMAPresseagentur, 1983). 
appearances at events within the esoteric scene, the Armanen-Orden was able to attract a significant contingent of younger members not only from the rightwing political spectrum but also from the broader alternative religious milieu. The racial-religious Artgemeinschaft entered a phase of renewal in the early 1980 s as well. It attracted a younger following, although not from the New Age and occultist contexts it rejected. This was due to the Hamburg right-wing lawyer Jürgen Rieger's activities. Rieger had forced Wilhelm Kusserow out of the organization and taken over the leadership in 1983, which he held until his death in 2009. ${ }^{4}$

The first groups in Germany that promoted a religion resembling modern Asatru were founded in the 1980 os by younger members of the Artgemeinschaft and the Armanen-Orden in Berlin. Out of the several alternately collaborating and competing small regional groups grew two groups, ${ }^{5}$ both of which are still active today: Heidnische Gemeinschaft and ANSE. The Heidnische Gemeinschaft (Heathen Community) was founded by Géza von Neményi in 1985. Neményi eventually left the group and reactivated Ludwig Fahrenkrog's Germanische Glaubensgemeinschaft (GGG) in 1991, harking back to one of the first Germanic Faith groups in Germany. ${ }^{6}$ These ethnicist groups were the first to turn away

4 Jürgen Rieger was widely known in Germany as a lawyer for right-wing extremists, neo-Nazis, and Holocaust deniers. In the 196os, he was active in the Bund Heimattreuer Jugend and later on in the racist Gesellschaft für biologische Anthropologie, Eugenik und Verhaltensforschung (Society for biological anthropology, eugenics and behavioral science). In his later years, he used his significant inheritance to finance centers for right-wing extremist organizations and youth groups and served as vice chairman for the right-wing party, NPD. Cf. Juliane Wetzel, "Die Maschen des rechten Netzes. Nationale und internationale Verbindungen im rechtsextremen Spektrum," in Rechtsextremismus in Deutschland. Voraussetzungen, Zusammenhänge, Wirkungen, ed. Wolfgang Benz (Frankfurt a.M.: Fischer, 1994), 171; Sven Röbel, "NPD-Vizechef Rieger ist tot," Spiegel Online, 29.09.2009, http://www.spiegel.de/politik/ deutschland/prominenter-rechtsextremist-npd-vizechef-rieger-ist-tot-a-658206.html, last accessed January 05, 2015; Ingolf Christiansen, Rainer Fromm, and Hartmut Zinser, Brennpunkt Esoterik. Okkultismus, Satanismus, Rechtsradikalismus (Hamburg: Behörde für Inneres, 2004), 149-152, Stefan v. Hoyningen-Huene, Religiosität bei rechtsextrem orientierten Jugendlichen (Münster/Hamburg/London: LIT Verlag, 2003), 232f.

5 Der Hain (The Grove) the journal of the Gemeinschaft für heidnisches Leben (Community for Heathen Life), a third group emerging in this context, has remained active as an internet publication (http://www.derhain.de/, last accessed February 26, 2014). Its editor Matthias Wenger is engaged in several Neopagan contexts. See also Chapters 8 and 9 .

6 For Ludwig Fahrenkrog and the original GGG see Chapter 1. The foundation of this group, which he wanted to become a significant umbrella organization for all Asatruers in Germany, brought Neményi into conflict with Jürgen Rieger's Artgemeinschaft, which also laid claim to being the direct successor to the Germanische Glaubensgemeinschaft. However, 
from Ariosophic beliefs and aim at reconstructing an allegedly authentic Germanic religion based on Old-Icelandic sources and relevant research within folklore and archaeology. They also installed statutes requiring their members to distance themselves from fascism and racism, holding fast to a strongly ethnicist line. Competing with the $G G G$ was another umbrella organization, the racial-religious Arbeitsgemeinschaft naturreligiöser Stammesverbände Europas (ANSE, Working Group of Nature Religious Tribal Associations of Europe), founded by Sigrun von Schlichting in 1990. For a number of years it served as a networking platform for different neo-Germanic groups, including the Armanen-Orden, the Artgemeinschaft, the Deutschgläubige Gemeinschaft, and organized national and later on international meetings.

The international network, to which the ANSE as well as the GGG belonged, also included the ethnicist English Odinic Rite, one of the earliest and most internationally influential post-war Heathen foundations. It goes back to the initiative of John Yeowell, who in his youth had been a member of the French Foreign Legion and a bodyguard for British fascist leader Oswald Mosley. ${ }^{7}$ Yeowell was inspired by John Gibbs-Bailey, who had been an Odinist since the 1930s (and thus had probably had contact with Alexander Rud Mills' teachings). ${ }^{8}$ In 1973, the two men, under the pseudonyms Stubba and Hoskuld, took the initiative of forming a Committee for the Restoration of the Odinic Rite, which dissolved and was converted into the Odinic Rite in 1979, and then registered as an official charity in 1988. With its slogan "Faith, Folk, Family" and the claim that Odinism is the "organic religion of the Northern-European peoples," 9

the courts ruled in favor of Neményi. Cf. Schnurbein, Göttertrost in Wendezeiten, 42; Katrin Riedel, "Von Gott und den Göttern. Eine komparative Untersuchung der neuheidnischen Germanischen Glaubens-Gemeinschaft(en)," Zeitschrift für Religions- und Geistesgeschichte 66, no. 3/4 (2014).

7 This claim was made by an early member of the $O R$, Stephen Flowers/Edred Thorsson. Cf. Edred, History of the Rune-Gild, vol. III (The Reawakening of the Gild 1980-2005) (Smithville, Tx: The Rune-Gild, 2007), 103.

8 It is not quite clear how strongly Yeowell was influenced in the beginning by Alexander Rud Mills' writings. Rud Mills is mentioned on the $O R$ website as an important promoter of Odinism, and his book The Call of Our Ancient Nordic Religion is for sale on the or website (http://www.odinic-rite.org/main/the-call-of-our-ancient-nordic-religion/, last accessed February 26, 2014). See also Hengest/on, "In Memory of John Yeowell - 'Stubba," The Odinic Rite, http://www.odinic-rite.org/main/in-memory-of-john-yeowell-\%e2\%80\%gcstubba\% e2\%8o\%gd/, last accessed June 03, 2011.

9 Cf. Schnurbein, Religion als Kulturkritik, 138. The account given there is based on information material by the $O R$, amongst others a flyer "Odinists say 'Yes!' to life." Many of the formulations there can also be found on the $O R$ 's homepage today. See www.odinic-rite.org. 
the tightly structured group, which bases its coherence on a system of life-long oaths, established itself as a leading ethnicist Asatru group early on.

Alexander Rud Mills' 1930s version of Odinism was particularly influential for one of the new groups in the USA, Else Christensen's Odinist Fellowship. The inception of the Odinist Fellowship is a prime example of the international roots of radical racial-religious Asatru. Else Christensen $(1913-2005)^{10}$ was a native of Denmark, where she was involved with both revolutionary unionism and the national Bolshevist wing of the early National Socialist movement at a young age. After her emigration to Canada in 1951, she further pursued "her interest in class-based racial radicalism"11 and discovered the writings of Alexander Rud Mills. Christensen combined Mills' theories with those of the American anti-Semitic National Socialist Francis Parker Yockey and with Jungian philosophy. From this, she developed Odinism as a racial religion. Initially it was designed as a discreet vehicle to establish her cultural pessimist, anti-Semitic and radical racial agenda in a religious cloak. It was thus not her primary interest to support a polytheistic religious agenda. Rather, she followed a path that is reminiscent of the German Faith Movement of the early 2oth century. Christensen was looking for cultural manifestations of the 'Germanic racial spirit' in an idealized Nordic past, which was to be emulated and revived by way of a 'retribalization' of society.

According to his own retrospective claims, the founder of the other influential early North American Asatru group, Stephen McNallen, did not have a racial agenda when he established the Viking Brotherhood around 1970, nor did his "pagan epiphany [...] spring from the leftist/hippy/Age-of-Aquarius counterculture of the 196os."12 Rather, it was spurred by an anti-clerical affect, "the perception that the God of the Bible was a tyrant and that his followers were willing slaves, and an admiration for the heroism and vitality of the Norsemen as depicted in popular literature."13 It was once his group was renamed the Asatru Free Assembly in the mid-1970s that he started adopting the ethnicist assumption of "an innate connection between Germanic Paganism and the Germanic peoples." ${ }^{14}$ The AFA developed a structure of regional subgroups, the Kindreds; and interest groups, the Guilds; and started devising rituals. Leading

\footnotetext{
10 The information on Else Christensen is taken from Gardell, Gods of the Blood, 166-174.

11 Ibid., 167.

12 Stephen A. McNallen, "Three Decades of the Ásatú Revival in America," in Tyr. Myth Culture - Tradition II, ed. Joshua Buckley and Michael Moynihan (Atlanta: Ultra, 2003/04), 205 .

13 Ibid., 205, cf. Kaplan, Radical Religion in America, 18.

14 McNallen, "Three Decades of the Ásatú Revival in America," 207.
} 
protagonists of later Asatru groups on the American continent, for example Edred Thorsson/Stephen Flowers (Rune Gild, Ring of Troth), Valguard Murray (Asatru Alliance), and Prudence Priest (Ring of Troth, later American Vinland Association) began their religious careers in the AFA. Accusations and internal controversies around the $A F A$ 's involvement with racists and National Socialists caused considerable turmoil in the 1980 s. It remains unclear to what degree these controversies contributed to the dissolution of the AFA around 1986.15 However, the disagreements around racial-religious and ethnicist versions of Asatru persisted into the 1990s, when former AFA members started the current leading Asatru groups in the USA (The Troth, Asatru Folk Assembly and the Asatru Alliance).

As we have seen, modern Asatru in Germany, Britain, and the UsA had links to völkisch religious ideology; either directly, as in the German case, or indirectly through Odinism, in the Anglo-American cases. Early attempts at installing Asatru as a religious alternative in the Scandinavian countries differ from this picture. They seem to mainly emerge out of counter-cultural impulses. This is true as well for the most nationally successful and most internationally important newly founded Asatru group of the 1970s, the Icelandic Ásatrúarfélagið (the Asatru Association or Ásatrúarmenn - 'Asatru-Men,' as they were called initially), which was formed around 1972. Nevertheless, this countercultural, a-racist group was supported considerably by a group called Nýalssinna in its years of establishment. This spiritist organization was founded in $195^{\circ}$ based on the writings of geologist Dr. Helgi Péturss. It combined spiritist, theosophical and nationalist ideas with scientific elements, claiming that the spirits who appeared in séances were inhabitants of other planets and communicated with humans through dreams and telepathic means. For Péturss, the Nordic gods were denizens of remote stars who had supposedly reached a higher level of consciousness. They were now active as spiritual leaders of mankind, speaking especially to the supposedly highly developed Icelanders. ${ }^{16}$

15 This is the conclusion Jeffrey Kaplan, Radical Religion in America, 19, draws, and Mathias Gardell, Gods of the Blood, 26o, follows. McNallen himself states the contrary: that the $A F A$ 's demise "had nothing to do with racial politics," but was due to him and his wife being overworked, and thus "unable to continue putting in the workload required to sustain the group without financial compensation." McNallen, "Three Decades of the Ásatú Revival in America," 208f.

16 Spiritism and theosophy had a unique position in Iceland as the "ideology of the new bourgeoisie and the middle classes," during the second and the third decades of the 2oth century. Spiritist ideas were instrumental in the process of nation building and the move towards independence from Denmark, which Iceland gained only in 1944. Medieval Icelandic sources on mythological themes, the Eddas and the Sagas, which held an 
According to church historian Pétur Pétursson, it was the support of members of Nýalssinna, not least its leader Pórsteinn Guðjónsson, which provided the organizational structure and PR know-how ${ }^{17}$ required to attain official government recognition as early as 1973 - a fact which gave rise to the suspicion that the group might have had ties to racist and even National Socialist ideologies. ${ }^{18}$ Such allegations were eventually refuted by pointing to the fact that National Socialism was not a Neopagan movement, but rather closely allied with the Christian churches, and also by combining the application for government recognition with a call for "true freedom of religion."19 The inner coherence of the membership (consisting of heterogeneous counter-cultural, anti-clerical and nationalist circles) and the development of rituals in the 1970 and 8 os was the work of one charismatic man: its religious leader, Allsherjargóf ${ }^{20}$ Sveinbjörn Beinteinsson (1924-1993). Having been attracted to Helgi Péturss' writings in his youth, ${ }^{21}$ the farmer and autodidactic poet of the traditional Icelandic genre

unquestioned status as foundational elements of Icelandic cultural heritage and thus also of constructions of national identity, were frequently read in the light of theosophical and spiritist theories. Cf. Pétur Pétursson, Church and Social Change. A Study of the Secularization Process in Iceland 1830-1930, vol. 4, Studies in Religious Experience and Behavior (Helsingborg: Plus Ultra, 1983), 164 and 169 f. See also Asasamfundet på Island och massmedia, ed. Religionssociologiska Institutet, vol. 185:1, Forskningsrapport (Stockholm: Religionssociologiska Institutet, 1985), 27 note 2, and 1-3.

17 Asasamfundet på Island och massmedia, 185:1, 10.

18 In the 1970s, much of the criticism was directed against Pórsteinn Guðjónsson, who tried to introduce overtly right-wing political issues into Ásatrúarfélagið. Although he was briefly successful with one resolution, taking a strong stance against abortion in 1974, he failed to establish this political direction within Asatru. He consequently founded a political organization, Norrcent Mankyn (Nordic Race) in 1982, as a forum for his antiimmigrant and pro-life views. Jonsson, "Ásatrú á Íslandi við upphaf 21. aldar," 151-153. Current Allsherjargodi Hilmar Örn Hilmarsson assesses this initiative in retrospect with the following words: "They were deservedly treated as anachronistic clowns." (Correspondence with Hilmar Örn Hilmarsson (Ásatrúarfélagið), 2012) The importance of Pórsteinn Guðjónsson for the international network of Asatru is discussed below.

19 Pétursson, Asasamfundet på Island och massmedia, 185:1, 7-12; Sveinbjörn Beinteinsson, Correspondence with the Icelandic Ministry of Justice and Church (Reykjavík: Archive Pétur Pétursson, 1972).

20 Allsherjargodi (All-warring chieftain) was a title in medieval Commonwealth Iceland for the person who was recognized as the Goði in the district of the first Norse settler in Iceland. It was his task to sanctify the annual assembly of chieftains, the Allthing. The Ásatrúarfélagið uses such medieval terms also for other functions within the group, the most important next to the Allsherjargodi being the "lawspeaker" (Lögsögumaður).

21 Cf. Correspondence with Hilmar Örn Hilmarsson (Ásatrúarfélagið). 
of Rímur was already a well-known character by the time he gained the status of a key figure for Asatruers worldwide.

Due to Iceland's official recognition of Asatru, its community became the most significant internationally. Sweden, by comparison, sported the most lively and diverse milieu in the Nordic countries. It was comprised of a number of small groups representing everything from loose networks to hierarchical initiatory groups, and from a-racist New Age interpretations of the Nordic to strictly ethnicist and nationalist understandings of Asatru. The first attempt to establish an organized group, the ethnicist Breidablikk-Gildet, was made in 1975 by Arne Sjöberg (1921-2000). Sjöberg had a background in Sweden's equivalent to the life reform movement, the teetotaling Frisksportrörelsen (Movement for Sport and Health). Breidablikk-Gildet was organized as an order, with an initial structure patterned after the Good Templars. It had its most successful period in the mid-1980s with an estimated 130 members, but folded after Arne Sjöberg's death in $2000 .{ }^{22}$ Its main goal was cultural, rather than religious in the narrow sense. Its focus was the cultivation of national tradition and history.

This ethnicist and nationalist orientation facilitated contacts to militant right-wing milieus, resulting in controversies with an a-racist group that was influential for the formation of later Asatru, the neo-shamanic network Yggdrasil. ${ }^{23}$ Yggdrasil grew out of a small group in Stockholm which cultivated an interest in neo-shamanism in the wake of the Carlos Castaneda's books' popularity. ${ }^{24}$ This group launched the journal Gimle, and founded a "Network for Nordic Shamanism” in 1982. American neo-shaman Michael Harner's visit to Sweden in 1983, and his courses on "core-shamanism," inspired more practical explorations of shamanism. Yggdrasil then went on to collectively design the Swedish version of seid. ${ }^{25}$

22 Fredrik Skott, Asatro i tiden (Göteborg: Språk och folkminnesinstitutet, 2000), 50; Gregorius, Modern Asatro, 91.

23 The fact that right-wing extremists were attracted to Breidablikk-Gildet was acknowledged by Arne Sjöberg himself. Criticism was raised in an article in Gimle, the journal for the shamanist network Yggdrasil, written in an attempt to refute alleged ties to BreidablikkGildet. See Interview with Arne Sjöberg (Breidablikk-Gildet), 1991; Schnurbein, Religion als Kulturkritik, 196f; Gregorius, Modern Asatro, 91.

24 Modern Asatro, 95.

25 A thorough study of the Yggdrasil community and their practice of seid is presented in Galina Lindqvist, Shamanic Performances on the Urban Scene. Neo-Shamanism in Contemporary Sweden, vol. 39, Stockholm Studies in Social Anthropology (Stockholm: Department of Social Anthropology, 1997). For a detailed discussion on different versions of seid and neo-shamanism see Chapter 3 . 
In contrast to Sweden and Iceland, Danish and Norwegian Asatru did not seriously emerge until the 1990s. An exception is a small group in Norway, which started as a counter-cultural student prank at the University of Oslo in 1983 and "grew out of a subculture with general interests in Paganism and the occult."26 The group went on to found Bifrost as an umbrella organization for Asatruers in Norway and tried to achieve official acknowledgement by the Norwegian state as a religious association, following in the footsteps of the Icelanders. The attempt failed, however, and the group went on to celebrate the occasional ritual (called blot), but ceased its activities in 1987 .

\section{In Search of Respectability - Asatru after 1990}

By the early 1990s, Asatru groups in Northern and Northwestern Europe, as well as in the USA, had established themselves as small and highly controversial participants within the spectrum of alternative religions. With regard to organization, they oscillated between the closed structures of occult orders and initiatory organizations, and those of more open, community-building religious groups. An international network of contacts between the most active leaders and group members was in place as well. All of this was accompanied by a structural pattern which also characterized the völkisch religious movement in the first part of the 2oth century, and which remains formative for the 'cultic milieu' of Asatru up until today. It is characterized by the frequent emergence of small groups that split as soon as they have reached a certain volume of membership, and by equally frequent attempts to reunite splinter groups and form umbrella organizations. Splits occur for different reasons, most of them not ideological. Instead, they tend to be related to financial or organizational issues and motivated by competing claims to leadership. In spite of these dynamics, there is considerable continuity in the milieu. It remains organized around a limited number of active individuals; core ideas as well as points of contention remain astonishingly stable.

According to Fredrik Gregorius, Yggdrasil became part of Merlinorden in 1997, Gimle continued to exist until 2004 and reported on the new group Sveriges Asatrosamfund in 1997. One of its central protagonists, Jörgen I. Eriksson, remains active as an author of books on shamanism as well as on Swedish folk magic and rune magic under the pseudonym Atrid Grimsson (cf. Gregorius, Modern Asatro, 98).

26 Egil Asprem, "Heathens Up North. Politics, Polemics, and Contemporary Norse Paganism in Norway," The Pomegranate 10, no. 1 (2008), 50. 
Nevertheless, the 1990s and 2000s brought a new quality to Asatru worldwide. Most countries saw the rise of new groups. Together with some of the older groups, they followed a course of integration into mainstream society and aimed at different forms of official acknowledgement from the respective state authorities. A stronger emphasis was placed on the inclusion of original sources and academic theory for the re-construction of a pre-Christian religion. A new strategy for the authentication of one's own religion developed. Many groups also started to distance themselves more assertively from overtly political agendas, from racism in particular. This path towards 'respectability' and desire for 'normalization' was motivated not least by the increasing negative media attention that the racist elements in Germanic Neopaganism had started to attract by this time. Books investigating the ideological and organizational right-wing connections of Germanic Neopaganism ${ }^{27}$ contributed to this attention, as did the more sensationalist press coverage. The latter was alternately concerned about neo-Nazi and Satanist tendencies in youth and religious sub-cultures, at times stoking up veritable moral panics. ${ }^{28}$ At the same time, Norway and Sweden in particular saw the rise of new radical racialreligious groups, such as the Allgermanic Heathen Front. Both developments elicited the need for a clearer delineation of Asatruers who perceived themselves as a-racist. Finally, this process of change was facilitated by the technological and communications revolution of the Internet, which the new groups in particular made use of quickly and effectively in order to spread their ideas, solicit members, and carry on their controversies.

\section{Norway}

Norway is the most obvious example of such a coincidence of the emergence of new right-wing extremist, racial-religious Asatru groups and the drive for "more mainstream" Asatru communities to "adopt[...] an explicitly anti-racist position." ${ }^{29}$ In 1993, black metal musician Varg Vikernes founded the racialreligious Norwegian Heathen Front during his stay in prison. ${ }^{30}$ In the same

27 Kaplan, Radical Religion in America; Schnurbein, Religion als Kulturkritik; Göttertrost in Wendezeiten.

28 See for example Asprem, "Heathens Up North," 44.

29 Ibid., 44.

30 The organization added other national chapters and the international umbrella Allgermanic Heathen Front $(A H F)$ throughout the years, but ceased to exist in 200o. Cf. Gardell, Gods of the Blood, 307. Two other groups, Vigrid, run mostly by Tore Tvedt between 1998 and 2009, and Det norske Åsatrosamfunn, claimed to build their religion and worldview on Norse mythology and/or folk customs. A visit to their websites shows that their emphasis on anti-Semitic or anti-monotheist sentiment stands more in the foreground 
year, the inactive Norwegian Åsatrofelleskapet Bifrost revived the idea to establish a nationwide a-racist Asatru organization, and resumed the process of applying for official government recognition. Two obstacles were to be overcome in this process. Firstly, an earlier application had failed because the group did not manage to formulate an official statement of creed; secondly, Asatru was perceived as a movement dealing with magic, an "antisocial and subversive practice" in the eyes of the authorities. ${ }^{31}$ In 1996, Bifrost was accepted as the first official Neopagan religious community in Norway and mainland Scandinavia. By 2001, the group had also submitted a marriage ritual to the state authorities that was subsequently recognized officially. ${ }^{32}$ Bifrost considers itself an umbrella organization for independent individuals and, currently, five regional groups (blotslag). Just as Bifrost had to formulate their creed within the frames of what is officially considered appropriate for a religion, it structured its organization according to official guidelines. Like any other religious association in Norway, Bifrost has a board consisting of a director, here called høvding (chief), a treasurer, and a secretary. Their responsibilities include running the association's daily affairs and managing its finances, which consist of membership fees as well as the state and communal support granted by the Norwegian government. ${ }^{33}$

In 1998, disagreements about administrational structures and details of beliefs led to the breakoff of a small faction of Bifrost members, who then established Foreningen Forn Sed (FFs, Association of the Old Way). The a-racist group continues to exist as an official religious association with a membership of approximately 70. It sports similar views to Bifrost, and the members I spoke to see few differences in beliefs and general opinions. However, they experience $F F S$ as more open and experimental regarding rituals and practices. Further, they appreciate the less rigid organizational structure, which lacks

than the elaboration of a religion. See e.g. http://vegtam.info/hundensminne/Hvorforaasatru.htm; http://www.vigrid.net/, last accessed February 26, 2014. For studies of Vigrid see also Astrid Espseth, "Stemplingens konsekvens? En studie av nynazistiske grupperinger" (Master's thesis, University of Oslo, 2007) and Lill-Hege Tveito, "Kampen for den Nordiske rases overlevelse. Bruken av den norrøne mytologien innenfor Vigrid" (Master's thesis, University of Tromsø, 2007).

Egil Asprem, "Heathens Up North" connects this perception with the mentioned 'moral panics' around "Satanism" which raged in the Norwegian press in the early 1990s. For details see Chapter 9 .

33 Cf. "Bifrosts lover" (Bifrost's Laws) http://www.bifrost.no/index.php?option=com_conten t\&task=view\&id=326\&Itemid=104, last accessed February 26, 2014. 
formalized local groups, and they reject the practice of having goder and gydjer as leaders for individual blotslag. ${ }^{34}$

\section{Sweden}

With the formation of the a-racist Sveriges Asatrosamfund (sas; Swedish Asatru Association) in 1994, Swedish Heathens established their first successful and sustainable national organization. Older ethnicist organizations such as Breidablikk-Gildet had only little influence on this group. ${ }^{35}$ Its founding members had roots in Yggdrasil as well as in the folklore association Järnåldersföreningen Birka (Iron Age Association Birka). ${ }^{36}$ The group initially consisted of about twenty mainly Stockholm-based members, but numbers grew quickly to 150 in 1996 when SAS started its own journal, Mimirs Källa (Mimir's Well), and rose to around $35^{\circ}$ by 2000 . This necessitated the establishing of regional and local subgroups called godeord. Controversies and problems around issues of leadership and finances, as well as a case of embezzlement, ${ }^{37}$ caused a number of members to leave the organization around 2004 and flock to two other Asatru associations: Nätverket Forn Sed (Network the Old Way), a loosely organized network of individual blotlag (ritual groups) with no central leadership, and Nordiska Ringen (Nordic Ring). The latter was founded in 2000 and changed its name to Norröna Samfundet (Norse Association) in 2003 when it was officially recognized as a religious association. ${ }^{38}$ A fierce debate ensued about Norröna Samfundet's ethnicist,

34 Interview $\mathrm{Q}$ and Interview $\mathrm{R}$.

35 An indirect line connects Breidablikk-Gildet to $S A S$, the small group Telge Fylking founded in 1987, which had close ties to Breidablikk-Gildet initially. Telge Fylking shared BreidablikkGildet's interest for a national cultural tradition, but turned to a more genuinely religious orientation as well, emphasizing its character both as a folk-religion and a religion of nature. Although it never had more than 25 members, Telge Fylking, and its journal, Ratatosk (1989-1994), was one of the two most significant sources of inspiration for later Asatruers in Sweden. Gregorius, Modern Asatro, 93 f.

36 Ibid., 10o. In an interview with the Danish Asatru journal Valravn, Mikael Perman, the former head of SAS contradicts his own involvement with Yggdrasil, stating that he learned shamanism in the USA, read Yggdrasil's journal Gimle, but was never a member, and kept shamanism completely out of sAs (Cf. Valdemar Ravn, "Interview med Mikael Perman," Valravn. Hedensk tidskrift om samfund og kultur 12 (2005), 11). The apparent necessity of such a refutation points to the fact that the neo-shamanic practices of Yggdrasil remain a point of contention within Swedish Asatru.

37 Cf. Gregorius, Modern Asatro, $104 \mathrm{f}$.

38 For a brief history of Norröna Samfundet see ibid., 113-115. 
genealogical interpretation of Asatru and the leading members' association with right-wing organizations. Shortly thereafter, in 2005, the group ceased its activities. ${ }^{39}$ SAS re-stabilized and achieved official recognition as a religious association in 2007. In 2009/10 its statutes and organizational structures were reworked, and the name was changed to Samfundet Forn Sed (SFS - Association The Old Way). ${ }^{40}$

In order to gain recognition and acceptance, $S F S$ has followed a similar strategy to, for example, Bifrost in Norway. It firmly rejects any racist or xenophobic interpretations of Norse mythology and emphasizes its democratic basis. This unambiguous stance has provoked criticism among other Swedish and Danish groups, who at times blame $S A S$ for being too narrow and exclusionist out of "political correctness." 41

On the other side of the political spectrum, Sweden has had its share of right-wing extremist, racial-religious groups as well. Most prominent for a while was Svensk Hednisk Front, a branch of the Allgermanic Heathen Front. It had considerable influence on nationalist movements in Sweden and Norway, not the least through its publishing company Nordiska Förlaget and its webportal for Nordic Identity, Culture, and Tradition (www.nordisk.nu). Whereas Allgermanic Heathen Front had been in decline since 2003 and stopped its activities in 2006, the publisher and the portal currently still seem to be functioning well. ${ }^{42}$

\section{Denmark}

The development of modern Asatru in Denmark is the best example of the paradigm shift that took place within the Heathen world in the late $1990 s$.

39 Ibid., 108-110.

40 http://www.samfundetfornsed.se/om-samfundet-1282525 (February 26, 2014). See also Sveriges Asatrosamfund, "Snart är de nya stadgarna här!," Mimers Källa 21 (2009), 5 f.

41 Gregorius, Modern Asatro, 107. "Political correctness" is used here not as an analytical concept, but as a term which has been used polemically by conservative and right-wing circles to discount emancipatory political positions.

Cf. ibid., 115-117. A different approach is followed by Samfälligheten för Nordisk Sed (Community for the Nordic Way). Founded in 1997, the group claims to follow a living, unbroken, but constantly changing folk tradition. In contrast to other Asatruers, they adamantly reject being counted among Asatru or Neopagan groups, because they feel that the others' faith is based on modern national Romantic constructions, whereas theirs is seen as authentic and firmly rooted in tradition. The group seems to be fairly small, has little contact with the general Asatru milieu in Sweden or elsewhere, and claims to be deliberately ignored by the media and general public. Ibid., 117 and http:// www.nordisksed.se/, last accessed February 26, 2014. 
During my initial research in Scandinavia around 1990, I was not able to find Asatruers in Denmark, and none of the Norwegian or Swedish groups with whom I was in contact could point me in the direction of any. By the time I started my new research in 2010, the nation-wide Forn Siðr (The Old Way or Old Custom) had become one of the most internationally significant and largest Asatru groups, officially acknowledged as a religious community with its own burial site and a fairly solid status within Danish society. What had changed?43

Only in 1997, after the arrival of the Internet and the successful establishment of popular history events such as Viking markets, a handful of individual Asatru practitioners, Viking enthusiasts, and 'net-Heathens' had established the organization and its journal, Vølse. Forn Siðr is a nationwide organization in which individuals can become members. As long as they can list a Forn Siðr member as an official contact person, independent blotgroups are given associate status. The existence of such an umbrella organization with common statutes and a ritual structure guarantees a fairly strong public support for Asatru in Denmark. A network of independent blotgroups on the other hand leaves ample room for a wide variety of sometimes loosely structured, sometimes very tight-knit, regional and special interest organizations. ${ }^{44}$

The early years were marked by the emerging community's efforts to obtain the status of an official religion by the Danish state. This would give them the authority to conduct publicly acknowledged rites like marriages, blessings of newborns, and funerals, as well as educating children about Asatru in schools. Their first official application was turned down by the Ministry of Church because the organizational structure, especially the relation between the blotgroups and Forn Siðr, was considered too loose and the minimal requirements for official rituals too vague. ${ }^{45}$ Because of this failure, Forn Siðr codified a more binding ritual structure in a similar way as Norwegian Asatru had done before. This not only demonstrates how Scandinavian Asatru interacts, but also how the interaction between state authorities and a previously loosely organized,

43 As I learned later on, a small local Asatru group, Odins Hird in Amager, a suburb of the capital Copenhagen, was founded in 1986. Cf. Valdemar Ravn, "Interview med en vølve," Valravn. Hedensk tidskrift om samfund og kultur 7 (2003).

44 Among them is, for example, Asatrofcellesskabet Yggdrasil, a loosely structured group that achieved its goal of buying and preserving a piece of land near Silkeborg in Central Jutland in 2004, and is currently branching out into regional subgroups. http://www .asatrofaellesskabet-yggdrasil.dk/, last accessed February 26, 2014.

The process of official acknowledgement and the relevant correspondences are documented on Forn Sidr's homepage: http://www.fornsidr.dk/om-forn-sidr/godkendelsesforloebet, last accessed February 26, 2014. 
non-committal religious movement can play a major role in the formation of a new religion. In 2003, this formalization of Forn Sidr's structures and practices was finally successful. Their official recognition as a religious community led to considerable media attention for the young group, and consequently a significant growth in membership - an effect that was repeated when the group was granted its first burial ground on a cemetery in Odense. In 2014, the group counted around 600 members.

The network of Asatru in Denmark has been supplemented by a number of independent groups with their own media of communication. Former Forn Siðr member Morten Grølsted (alias Grølheim), who had been dismissed from the organization, ran the ethnicist Asatrofcellesskabet (The Asatru Community), and more importantly, edited the journal, Valravn. Between 2002 and 2008, this journal provided the only international platform for Scandinavian Asatruers. It provided information about groups in other countries and took up a number of controversial issues over the years. ${ }^{46}$ In 2005 , a heated debate as to whether Asatru in general, and Valravn in particular, was taking a turn to the political right broke out between Valravn and another Danish discussion forum, the now-defunct online board Kindir run by an informal network since 2004/05 with the goal of educating people about Asatru. Kindir functioned, among other things, as a critical platform for speaking out against ethnicist, latently racist, right-wing and cultural essentialist positions within Asatru, and brought some of the controversies within Forn Siðr to a broader Heathen public. ${ }^{47}$

Danish Asatru has had no controversies with overtly racial-religious groups in the country, but stormy debates about the significance of ethnicist positions within the self-professed a-racist Forn Siðr have shaken the milieu in recent years. ${ }^{48}$ The disputes motivated a number of long-term or even founding members of Forn Siðr to form Nordisk Tingsfeellig (NTF, Nordic Ting Community) in December, 2010. NTF aims to develop a clearer a-racist profile than Forn Siðr, which in their eyes has made itself vulnerable to political agendas through its

$46 \quad$ Valravn understood itself as an open and deliberately controversial forum for all varieties of Asatru. Aside from speaking out against right-wing extremist groups such as the Heathen Front, and for more progressive sexual politics, it also gave voice to ethnicist and ethno-pluralist positions within Heathenism as well as to pro-Hindu nationalist, antiMuslim, anti-Christian and anti-Jewish sentiment. On Hinduism, see Valravn 1 (2002), 7 (2006), 23 (2007). On underlying anti-Christian and anti-Jewish sentiment see 1 (2002), 25; 3 (2002), 24; 12 (2004), 7 .

47 www.kindir.dk, last accessed December 07, 2010.

48 These controversies which circle around 'anti-monotheistic' positions are discussed in detail in Chapter 5 . 
principle of openness to all political persuasions that are not directly National Socialist. Their first published statements were a codex and a declaration, in which they formulate their allegiance to the ideals of multiculturalism, environmentalism, and the rejection of all those who connect religion to race, blood, genes and ethnicity. ${ }^{49}$ The community's long-term goals include its registration as an official religious community and the acquisition of land where Asatru celebrations can be held..$^{50}$

\section{Iceland}

As mentioned, the Icelandic Ásatrúarfélagið attained official recognition much earlier than any other Asatru community did. Nevertheless, the death of its first Allsherjargodi, Sveinbjörn Beinteinsson, in 1993 and the activities of his successor, Jörmundur Ingi Hansen, who had previously taken care of a large part of the official media representation and international liaison, ${ }^{51}$ marked a shift in the history of this group. The creation of a burial ground and the purchase of a house in Reykjavík as a center for the group motivated a considerable expansion. The Ásatrúarfélagið lost its image as a gathering place for outsiders and made its way into mainstream society. In light of the group's rapid growth, the membership demanded that the increasing institutional and administrative obligations be distributed among other elected office-holders, but Jörmundur Ingi insisted on keeping them under his control. In 2002, the conflict culminated in his removal from office. The following year Hilmar Örn Hilmarsson, the well-known composer and musician, ${ }^{52}$ took over as Allsherjargodi with Jörmundur Ingi's approval. ${ }^{53}$ Since then, the group has expanded continually, and its integration into Icelandic society has been solidifed. ${ }^{54}$ On the other hand, international relations, which Jörmundur Ingi Hansen had energetically pursued (also with members and

\footnotetext{
49 Cf. http://www.nordisktingsfaellig.dk/9303/Om\%20os, last accessed March 09, 2014.

5o Cf. http://www.nordisktingsfaellig.dk/9703/, last accessed March 09, 2014.

51 In this capacity, I conducted an interview with him in 1991.

52 Hilmar Örn Hilmarsson worked with the 'industrial' groups Psychic TV and Current 93 (cf. Stéphane François, "Les paganismes de la Nouvelle Droite (1980-2004)" (Doctoral thesis, Université de Lille II- Droit et santé, 2005), 211). He wrote the music for the internationally acclaimed movie Children of Nature, directed by Friðrik Pór Friðriksson (1991), and a great number of other renowned Icelandic films.

53 In 2006, Jörmundur Ingi formed his own group Reykjavíkurgoðord, Jonsson, "Ásatrú á Íslandi við upphaf 21. aldar," 12gf.

54 Interview with Óttar Ottóson (Ásatrúarfélagið). Ottósson claims that the membership was 98 in 1990, in 2005 it had gone up to 953, in 2010 to around 1500, by 2014 it had risen to around 2500 .
} 
leaders of racial-religious and ethnicist groups such as the Armanen-Orden and the Odinic Rite), ${ }^{55}$ were toned down and the association worked more within its own country. ${ }^{56}$ With currently around 2500 registered members (in 2014), the group is still small, but in relation to the total number of Icelanders (approximately 320,000) it constitutes a considerably higher percentage of the general population than in other countries. The somewhat exceptional position of Ásatrúarfélagið within its own country has two explanations. Firstly, Norse mythology and medieval Icelandic texts are considered an integral and important part of the Icelandic national heritage and identity, and are well known to most Icelanders from their school years. Hence, the Ásatrúarfélagið considers the preservation of an ancient Nordic culture as one of its main functions. Some of its members are not even primarily interested in religious issues, but rather in the preservation of such a cultural identity. ${ }^{57}$ Secondly, Ásatrúarfélagið has managed to establish itself as an alternative to the Lutheran Icelandic state church and has even attracted a few atheists and agnostics who sought an affiliation with a non-Christian denomination. ${ }^{58}$

\section{United Kingdom}

In spite of a temporary split of the organization in $1991,{ }^{59}$ the ethnicist Odinic Rite developed into a well-established group and expanded internationally, forming branches in the United States, France, and Germany over the years. ${ }^{60}$

55 For these connections see below, chapter "Asatru International."

56 See Interview with Óttar Ottóson (Ásatrúarfélagið).

57 Interview with Óttar Ottósson (Ásatrúarfélagið).

$5^{8}$ Cf. Interview with Óttar Ottóson (Ásatrúarfélagið). Ásatrúarfélagið’s status as an established religious community beyond the Lutheran National Church for a time also brought the group some exceptional members: a flock of Russian Orthodox refugees, who did not want to join either the State Church or the Roman Catholic community, but who as foreigners were obliged to be members of an officially acknowledged religious community in Iceland. They inscribed themselves into Ásatrúarfélagið and used their space for annual meetings for a while. Cf. Jonsson, "Ásatrú á Íslandi við upphaf 21. aldar" 149.

59 In 1989, John Yeowell resigned from his post as the director of the Court of Gothar, and Heimgest took over the office in which he has been serving up until today. In 1991, an expelled member of the $O R$ founded a rival organization under the same name, which Stubba joined for a brief period. However, he returned to the original $O R$ later, and the new organization was renamed Odinist Fellowship. See Hengest/or, "In Memory of John Yeowell - 'Stubba'; and http://www.odinistfellowship.co.uk/, last accessed February 26, 2014.

6o For the split of the German branch from the British mother organization see below. 
However, some of its members' far-right political associations and sympathies made it increasingly contentious. Some of these controversies had repercussions for the overall Neopagan community in the U K, since Pete Jennings, High Gothi of a competing Asatru group, the a-racist Odinshof (founded in 1987 and more strongly connected to Wicca), served as the head of the influential Pagan Federation for a number of years. ${ }^{61}$ Because of these problems, two former $O R$ members, Mike Robertson and Stuart Prior, left the group and founded Kith of Yggdrasil in 2001. Kith of Yggdrasil has around 50 members by now; it is counted among the a-racist groups, and is actively networking with Asatru groups in Scandinavia and Germany. ${ }^{62}$

In contrast to other countries, Heathenry in the UK is considered an integral part of the broader Neopagan scene, on par with Wicca and Celtic groups. Asatruers are less likely to be formal members of groups in the UK and tend to practice their religion independently. They connect through mailing lists, Internet forums, ${ }^{63}$ and gatherings organized by the general Pagan community. Pete Jennings observes that there is "less need for social networking organizations for Heathens. Greater openness, Internet groups and coverage in the general Pagan press \& conferences result in less need for that aspect." 64 At the same time, two groups originating in the USA have established branches in the UK. One of them, the Rune Gild, an initiatory organization for runic magic established by Edred Thorsson in 1980, has been headed by musician Ian Read ${ }^{65}$ since its founder Freya Aswynn's falling out with Edred Thorsson around $1993 \cdot{ }^{66}$ It enjoys a good reputation in the Pagan scene. ${ }^{67}$ The other group to have established a UK branch is The Ring of Troth, also initiated by Freya Aswynn. After being dormant for a while, it seems to have resumed

61 Cf. Correspondence with Pete Jennings (Odinshof), 2010. Odinshof was established by Martyn Taylor and John Broughton, and registered as a religious and educational charity in 1989. Honoring all Germanic and Celtic deities as well as local sacred sites and "promoting a mystery cult of Odin," the Odinshof had closer contact with Wiccan organizations than with Odinists. See Schnurbein, Religion als Kulturkritik, 140, as well as "Odinshof. The Way of the Raven" (http://www.gippeswic.demon.co.uk/odinshof.html, last accessed February 26, 2014).

62 Correspondence with Alan Nash, 2010.

63 See for example http://groups.yahoo.com/group/ukheathenry/, last accessed February 26, 2014.

64 Correspondence with Pete Jennings (Odinshof).

65 For more on Read see Chapter 9.

66 Cf. Edred, History of the Rune-Gild, III (The Reawakening of the Gild 1980-2005), 110.

67 Correspondence with Pete Jennings. 
some activity. ${ }^{68}$ One of its members is Jenny Blain, an ethnologist and prolific writer on Asatru. ${ }^{69}$

\section{USA}

When the Asatru Free Assembly faltered in the mid-1980s, two new groups emerged, and have since struggled for hegemony while developing North American Asatru into opposing ethnicist and a-racist directions. Stephen McNallen formally turned over the remains of the $A F A$ to Valgard Murray, who was then heading the Arizona Kindred, and to Robert N. Taylor from the Wulfing Kindred, who in turn started the ethnicist Asatru Alliance. ${ }^{70}$ Another long-term member of both the AFA and the Odinic Rite, and founder of the initiatory Rune Gild, Stephen Flowers (alias Edred Thorsson), started The Ring of Troth in 1987 together with James Chisholm. This organization was eventually to bring new impulses to Asatru not only in North America but in Europe as well. In the early 1990s, accusations of Satanism ${ }^{71}$ and racism ${ }^{72}$ led to a number of rapid changes in leadership and structure, the withdrawal of Thorsson and Chisholm from The Troth as well as the split off of another group, Prudence Priest's American Vinland Association (started in 1995). ${ }^{73}$ Today, The Troth is established as the largest and most active a-racist Asatru group in the USA, led by an elected steersperson and board called High Rede. ${ }^{74}$ Like the Asatru Alliance,

68 Cf. Correspondence with Pete Jennings (Odinshof); http://www.troth.org.uk/history.htm, last accessed February 26, 2014.

69 See Blain, Nine Worlds of Seid-Magic.

70 Valgard Murray had a background in the National Socialist wing of the radical right, where he learned about Odinism, Alexander Rud Mills, and Else Christensen. His Arizona Kindred was the first to be officially affiliated with the Odinist Fellowship, where Murray eventually became vice president. In 1984 he and his kindred changed affiliations and became part of the $A F A$.

71 The accusations were based on the fact that Thorsson and Chisholm were members of Michael Aquino's occult order Temple of Set. Cf. Kaplan, Radical Religion in America, 26. See also Edred, History of the Rune-Gild, III (The Reawakening of the Gild 1980-2005), 90-93.

72 These problems had to do with the involvement of Theodism, an Anglo-Saxon version of Heathenism, with The Troth. Theodism's ancestral and racial approach caused considerable turmoil. See http://gamall-steinn.org/Gering/gerthist.html, last accessed March 19, 2014, cf. also Garman Lord, "The Evolution of Theodish Belief. Part I," THEOD Magazine Lammas (1995), "The Evolution of Theodish Belief. Part II," THEOD Magazine Hallows (1995).

73 Cf. Kaplan, Radical Religion in America; 29, Gardell, Gods of the Blood, 164.

74 Cf. Kaplan, Radical Religion in America, 31; Kveldulf Gundarsson, ed. Our Troth, by Members of the Troth and Other True Folk, 2. ed., 2 vols., vol. I (History and Lore), vol. II (Living the Troth) (North Charleston, sc: BookSurge, 2006), 119. 
The Troth serves as an umbrella under which various regional groups called 'kindreds', 'hearths', 'garths' and 'hofs' gather. In the formative 1990s and 20oos, The Troth aimed at creating a training program for clergy within Asatru and put considerable emphasis on and effort into providing knowledge about what they call 'The Lore,' i.e. academic and popular information about Scandinavian, German and Anglo-Saxon myth, religion, culture, folk-customs etc., upon which the reconstruction of a faith can be based. All of these elements have made The Troth a forum that is sought out for its knowledge of sources and practices by many Asatruers. This and the emphasis on anti-racist and nonfolkish policies have been deciding factors for The Troth's international influence within a-racist Asatru.

However, its emphasis on knowledge, theory and sources has provoked critique as well, for example, from the ethnicist Asatru Alliance for being overly academic, for "coming from the head" and not being action-based enough. ${ }^{75}$ This already highlights the fact that the Asatru Alliance in its continuing development put a stronger emphasis on the building of community. The same is true for the Asatru Free Assembly, which was reestablished under the new name Asatru Folk Assembly in 1994 by Stephen McNallen. He claims he was motivated by his resentment of "signs that the politically correct faction" or "the universalists" in Asatru were "making inroads into territory long dominated by the folkish." ${ }^{76}$ Since then, the $A F A$ 's activities have fluctuated. In the last few years, McNallen and the $A F A$ have put considerable effort into community building in the virtual word as well as the real, with an active homepage (www .runestone.org), a Facebook presence, YouTube interviews, radio programs, a blog, and a podcast.

Racial-religious Asatru in the USA has been active in prison outreach. Forming prison ministries was an activity which Else Christensen had initiated, and which, up until today, seems to have remained a specialty of Odinist groups, not least the Odinic Rite. ${ }^{77}$ Prison outreach took on a new dimension

\footnotetext{
75 Cf. Kaplan, Radical Religion in America, 30.

76 McNallen, "Three Decades of the Ásatú Revival in America," 21of. During this time, the AFA seems to have had cordial ties with Ron McVan, a visual artist active in the radical racist Odinist group Wotansvolk and the 14 Word Press, together with David and Katja Lane. An editorial in The Runestone 9, Fall 1994, 5 hails Ron McVan as "one of Asatru's most prolific and talented artists," whose "drawings are frequently found in THE RUNESTONE." On McVan, Wotansvolk and 14-Word-Press cf. Gardell, Gods of the Blood, 205-216.

77 For a discussions on prison outreach see Gods of the Blood, vol. I, 175f; Gundarsson, Our Troth, 112; Jeffrey Kaplan, ed. Encyclopedia of White Power. A Sourcebook on the Radical Racist Right (Walnut Creek: Altamira Press, 200o), 361.
} 
with the foundation of the white supremacist Odinist group Wotansvolk, which was registered as a church under the name Temple of Wotan in 2000. Through their professional use of the Internet, Wotansvolk and 14 Word Press $^{78}$ succeeded in spreading their white supremacist, Ariosophic and Jungian-inspired ideology internationally.

\section{Germany}

In Germany, the direct connection to völkisch religion and German Faith became an increasing burden for Germanic Neopagans. While the ArmanenOrden decreased its public activities, Sigrun von Schlichting intensified her contacts with Eastern European Pagans such as the Romuva in Lithuania, and moved to a castle in Poland where she remained in active contact with Heathen groups and individuals until her death in 2009. ${ }^{79}$ Younger Asatruers started publicly distancing themselves from connections with the Armanen-Orden and the ANSE. ${ }^{80}$ Such actions were not only spurred by criticism of right-wing religiosity in the media, but also taken up by the Neopagan community itself. In 1994, the Rabenclan (Raven's Clan), an association for different Pagan traditions, was founded. It fought against völkisch and racist traditions and activities within Neopaganism. Asatruers in the Rabenclan started a working group, the Ariosophieprojekt, to actively investigate connections between völkisch ideology, right-wing extremism and Germanic Neopaganism. ${ }^{81}$ This small a-racist Asatru faction, which today calls itself Nornirs \&tt (Kin of the Norns), declared its formal independence from the Rabenclan in 2005. ${ }^{82}$ It remains a

78 According to Gardell, Gods of the Blood, 191, the notorious "14 words" which Wotansvolk founders David and Katja Lane coined "We must secure the existence of our people and a future for White children" is "one of the very few concepts that has won almost universal acceptance in the notoriously factious milieu of white-racist revolutionaries."

79 Cf. Andrzej Szczudlo, "Schlichtingsheim. Das 'Feenschloss' Rothenhorn der Frfr. Sigrun v. Schlichting," Neuer Glogauer Anzeiger, September, 2005.

8o This was not least a result of the publication of my books (Schnurbein, Religion als Kulturkritik; Göttertrost in Wendezeiten) and media discussions.

81 The Rabenclan's early activities on the Internet contributed significantly to the spread of this information. Over the years, the Ariosophieprojekt has provided well-researched background material, which has also been used by researchers and journalists. It gave the Rabenclan and its Asatru group Nornirs Ætt the reputation of a critically informed, politically engaged faction within the Neopagan scene in Germany. On the other hand, its political criticism of some groups has elicited refutations and allegations of slander from other Germanic Neopagan groups. Cf. http://www.nornirsaett.de/doc/ario/ario.html, last accessed February 26, 2014.

82 Cf. http://www.rabenclan.de/index.php/Aktuelles/AktuellesNornirsAett, last February 26, 2014, and Interview with six members of Nornirs Ætt, May 2010, Iceland. 
small group, with just over twenty members located in different regions of Germany and Austria. It is still set apart within the milieu through its explicit political positioning. Acknowledging that Germanic Neopaganism since the early 2oth century has been closely connected with national Romantic, völkisch and racist tendencies, Nornirs Ett feel they have a responsibility to counteract these and to engage actively in the development of a democratic, pluralistic society. Other German Heathens tend to perceive this political positioning as a distraction from religious goals proper, and consider it sufficient to follow a general 'un-political' policy.

Their political line pits the Rabenclan and Nornirs \&tt against not only the Armanen-Orden, the ANSE, and the Germanische Glaubensgemeinschaft, ${ }^{83}$ it also sets it apart from another new group, the Odinic Rite Deutschland (ORD, later renamed as Verein für germanisches Heidentum VfgH, Society for Germanic Paganism). ${ }^{84}$ The ORD started out as a chapter of the British Odinic Rite in 1994, representing an ethnicist wing in German Asatru. Concerns about the mother organization's turn toward the extreme political right were voiced in the ORD's journal, Ringhorn, as early as $1995 .{ }^{85}$ That, combined with differences in structure, ideology, and practices, led the $O R D$ to declare its independence. Between 2004 and 2010, VfgH doubled its membership from around 40 to 80, while developing a number of new regional groups called Herde (Hearths) and establishing itself as a small, but influential Germanic Neopagan group in Germany. The VfgH's statutes require a fairly strong personal commitment from each member. ${ }^{86}$ This idea of collective commitment, combined with the individual freedom to formulate one's own beliefs and design one's own religious

83 The GGG intensified its efforts to become a forum for all Germanic Neopagans in Germany in the 199os. Géza von Neményi's attempt to proclaim himself as the leader (Allsherjargodi) for "all traditional Germanic Heathens" in 2003 is today considered a failure within the community and its observers, cf. Gründer, Blótgemeinschaften, 59f, Matthias Pöhlmann, "Streit um Heiden-Papst - Géza von Neményi erhebt Führungsanspruch innerhalb des Neuheidentums," Materialdienst Evangelische Zentralstelle für Weltanschauungsfragen 66, no. 11 (2003). In 2007, two former members of the GGG formed their own group, Wodans Erben (Wodan's Heirs), which is active up until today as well. Cf. Wodans Erben, Gemeinschaftsblatt, vol. Ausgabe 2010 (Berlin: Wodans Erben e.V., 2010).

84 The Rabenclan published a long discussion of the $O R D$ 's political position on its homepage in 2005. Cf. Berna Kühne-Spicer, "Der Odinic Rite Deutschland - Neuheidentum im Spannungsfeld neurechter Religiosität," Rabenclan e.V., http://www.rabenclan.de/index .php/Magazin/KuehneSpicerORDKapı last accessed February 26, 2014.

85 See Fritz Steinbock's editorial in Ringhorn 8 (1995) titled "Ehre" (Honor).

86 Cf. "Mitgliedschaft im VfgH," http://www.vfgh.de/data/te_2.asp?MLEVEL1=20\&MLEVEL2 =40, last accessed February 26, 2014 . 
practice, is the essence of the "Leitidee freies Heidentum" (Guiding Idea of a Free Heathenism), which the $V f g H$ promotes as its unique trademark within the international Asatru community. It implies the rejection of privileged religious mediators, spiritual authorities, and leadership, making priesthood accessible to all members and limiting the function of priest-like Blótmen/ women exclusively to the conduct of rituals. ${ }^{87}$

The largest and youngest of the new Asatru groups in Germany, the a-racist Eldaring (Old Norse "eldr" means fire) differs from both Nornirs \&tt and the $\mathrm{VfgH}$ in its conception of itself as not a tight-knit religious community, but as a contact and service platform - a network for Asatruers who perceive of their faith as a personal and private matter. ${ }^{88} \mathrm{Like}$ the $\mathrm{VfgH}$, it developed out of a foreign Asatru group, in this case The Troth, into an independent organization in 2000. According to founding members, the appeal lay in The Troth's a-racist agenda and the significance it assigned to reconstructing Asatru from sources and research the Eldaring adapted. The central position of the Eldaring within German and international Asatru can be attributed to several factors; first, its character as an open platform requiring little commitment from its members; second, its unpolitical approach; third, its emphasis on academic research, which gives it an air of authenticity and respectability; and finally, the existence of active local Herde (Hearths), Blót Communities, special interest groups and annual events. The relative openness to elements of general Neopaganism and Wicca make it attractive for the around 200 registered members as of 2014 .

Controversies between the different groups continue to exist, in spite of their shared emphasis on reconstructing Asatru from written sources and in accordance with contemporary research. In recent years, disputes have focused on $\mathrm{VfgH}$ members' ethnicist sympathies and engagement in right-wing extremist parties. ${ }^{89}$ Another point of contestation is the small alternative publishing

87 See "Allgemeine Konzepte des VfGH im Überblick," http://www.vfgh.de/data/TE_2. asp?MLEVEL1=20\&MLEVEL2=10, last accessed February 26, 2014. While a number of ideological parallels can be found to Géza von Neményi's GGG, this emphatic rejection of priesthood marks a pronounced difference between the groups - a difference which can be compared to the distinction between Ludwig Fahrenkrog's $G G G$ and Otto Sigfrid Reuter's Deutschgläubige Gemeinschaft in the 1910s and 20 .

88 Cf. for example Interview with Uwe Ehrenhöfer (Eldaring). It is a statement that I have found in many other interviews as well.

$89 \quad V f g H$ member, Volker Wagner (Stilkam), is a controversial figure because of his open embracing of folkish Asatru and his translations of Stephen McNallen's articles about metagenetics (see Chapter 4). Furthermore, Thilo Kabus used to be a member of the right-wing extremist party NPD (National Democratic Party of Germany) and worked for 
company, the Arun Verlag, which has supported Asatru and other Neopagan endeavors. Arun's owner, Stefan Björn Ulbrich, has a background in right-wing extremist organizations in Germany, which he later publicly renounced as "youthful indiscretions" (Jugendsünden).${ }^{90}$ Ulbrich himself wrote a book on Germanic Neopagan religion and ritual, Im Tanz der Elemente (In the Dance of the Elements, 1990), where he drew upon Germanic Faith and Conservative Revolutionary ideas from the early 2oth century. Arun started out publishing New Right and Ns-occultist titles, but in the mid-19gos turned increasingly toward Neopagan and nature spirituality, neo-shamanism, esoteric self-help, and healing, gradually eliminating right-wing titles such as Julius Evola's Revolt Against the Modern World from its book-lists. ${ }^{91}$ Within the scene and beyond, the credibility of Ulbrich's recent distance from right-wing organizations and ideologies is a matter of controversy, and accordingly, individual Asatruers' affiliation with Arun remains a difficult topic.

\section{Asatru International}

Day-to-day, Asatru groups are primarily involved in their own affairs; most contacts and controversies between groups remain limited to their respective national context. At the same time, Germanic Neopaganism has always had an internationally active network at its disposal. Ideas and influences have been routinely exchanged, even though these interactions often happen through individual contacts and the majority of members might not always be aware of them.

Already the key figure for the formation of Odinism in Australia and the Anglo-American world, Alexander Rud Mills received at least some of his core ideas from German völkisch religion. After World War II, those ideas were dispersed by Danish-born Else Christensen in the USA and taken up by the British Odinic Rite, one of the groups that played a key role in the development of the

another right-wing party later on. Cf. Matthias Pöhlmann, "Trügerischer 'Heidenspass'? Das '1. Berliner Heiden- und Hexenfest' im Spiegel interner Kritik," Materialdienst Evangelische Zentralstelle für Weltanschauungsfragen 11 (2004); see Kühne-Spicer, "Der Odinic Rite Deutschland - Neuheidentum im Spannungsfeld neurechter Religiosität” for an in-depth discussion of possible right-wing involvements of some ORD members (the article was written before the name change to $\mathrm{VfgH}$ ).

9o The text has since been removed from Arun's homepage, but is quoted here: http://www .taz.de/1/archiv/archiv/?dig=2003/o6/16/ao252, last accessed February 26, 2014.

91 Cf. also Gründer, Germanisches (Neu-)Heidentum in Deutschland, 55-58. 
international Asatru network. Throughout the 1980s, the $O R$ developed a set of rituals eventually codified in the Book of Blótar, which was widely distributed throughout the Germanic Neopagan community in the 199os, providing inspiration for other groups in forming their rituals. Another major contribution of the $O R$ to the international Heathen community was the formulation of the "Nine Noble Virtues,"92 a moral code widely used by Asatru groups in Englishspeaking countries and beyond. The $O R$ acquired this key role by admitting foreign members and, through the process of initiation, giving them a status within their own countries' Odinist and Asatru milieus. These include prominent founders of other groups, such as Edred Thorsson from the Rune Gild and the early Ring of Troth; Freya Aswynn from the Ring of Troth UK; Valguard Murray, the early AFA member and founder of the Asatru Alliance in the United States; ${ }^{93}$ Volkert Volkmann, founder of the Yggdrasil Kreis in Germany; and Bernd Hicker (alias Thorbern), one of the founders of the Odinic Rite (later $V f g H)$ in Germany. ${ }^{94}$ The $O R$ also played a significant role in the short-lived attempt in 1997 to unite leading Asatru groups internationally in the $I A O A$ (International Asatru/Odinist Alliance), initiated by Valguard Murray, Stephen McNallen, and Heimgest, the leader of the Odinic Rite, and later joined by the French and German branches of the $O{ }^{9} .{ }^{95}$

The Icelandic Ásatrúarfélagið had less practical but more symbolic significance for the Asatru movement. After the group's official recognition in 1973, it attracted considerable international attention. One of its founding members,

The original nine noble virtues, which can be found on the $O R$ website (http://www .odinic-rite.org/virtues.html, last accessed November 03, 2010), read as follows: "Courage, Truth, Honour, Fidelity, Discipline, Hospitality, Self-Reliance, Industriousness, Perseverance." A number of modified versions are currently in use by other groups. Cf. Gardell, Gods of the Blood, 263.

94 In the 1990s, the ORD collaborated with the Yggdrasil-Kreis, which combines Celtic and Germanic elements into a "European religion of nature." The membership of Volkert Volkmann in the $O R$ is mentioned on a German site on geomantics (http://www .geomantie.net/authors/988/view.html, accessed February 26, 2014) as well as in a critical article on the $O R D$ by Berna Kühne-Spicer, "Der Odinic Rite Deutschland - Neuheidentum im Spannungsfeld neurechter Religiosität.” Volkmann's contact with the ANSE and the Armanen-Orden in the 1990 s is a matter of dispute. Volkmann emphatically denies having been a member of these organizations, and the Yggdrasil-Kreis has published numerous refutations of such claims on its homepage (http://www.yggdrasil-kreis.org/ html/gegendarstellungen.html, last accessed February 26, 2014). See also the critical reflections on these matters by Lucas Corso on the Rabenclan's homepage (http://www .rabenclan.de/index.php/Magazin/LucasCorsoVolkmann, last accessed February 26, 2014). 
the controversial head of Nýalssinna, Pórsteinn Guðjónsson, played a more active role in the international Asatru network. He started the English-language journal Huginn \& Muninn, which was distributed internationally. He was in close contact with Sigrun von Schlichting from the Armanen-Orden and ANSE (whose German-language journal adopted the same name), as well as with Géza von Neményi from the Heidnische Gemeinschaft and later the GGG. ${ }^{96}$ Both travelled to Iceland in the 1980 s and established contact with Jörmundur Ingi Hansen. Together, they facilitated the first international Flax Harvest Celebration, held in Iceland in 1988. It was followed by the participation of ANSE and Armanen-Orden members at the Odinic Rite's National Moot in $1990 .{ }^{97}$

We can conclude that already by the early 199os, an international network of racial-religious and ethnicist Asatruers had emerged, which expanded into Eastern Europe and in particular to the Lithuanian Romuva ${ }^{98}$ after the fall of the Iron Curtain. It acted as the taproot for the World Congress of Ethnic Religions (WCER), an international attempt to unite 'indigenous' religious groups under one roof. ${ }^{99}$ At its official foundation in 1998, Romuva's long-term leader, the ethnologist Jonas Trinkunas, became the first head of the WCER. The Icelandic Ásatrúarfélagið, Danish Forn Siðr, and the German GGG were among its original members. ${ }^{100}$

In spite of the fact that the term 'ethnic' was disputed from the beginning, ${ }^{101}$ the World Congress of Ethnic Religions quickly gained sympathy among

96 In a contribution on GGG's online forum, Neményi emphasizes this connection with Pórsteinn Guðjónsson, his visit to the GGG in 1992, his contribution to its journal Germanen-Glauben, and the fact that his son is a member of "our GGG-Ring": http://www .ggg-world.net/forum/showthread.php?tid=29o, last accessed February 26, 2014.

Schnurbein, Religion als Kulturkritik, 218. Sigrun von Schlichting and her ANSE also held contacts with Arne Sjöberg of the Breidablikk-Gildet in Sweden as well as with Thorbjørn Ragnarsson of Norges Åsatrolag in Norway. (Cf. ibid., 211). It also seems to have attracted the early AFA'S attention. The Armanen-Orden was listed by the AFA among the "more positive groups, and ones more allied with us." Ibid., 132, cf. Runestone Spring 1982, 12.

98 Vilius Rudra Dundzila, "Baltic Lithuanian Religion and Romuva," Tyr. Myth - Culture Tradition 3 (2007).

99 For a brief account of the foundation of the WCER see Michael Strmiska and Vilius Rudra Dundzila, "Romuva. Lithuanian Paganism in Lithuania and America," in Modern Paganism in World Cultures. Comparative Perspectives, ed. Michael Strmiska (Santa Barbara, CA: ABC-Clio, 2005), 276-278.

100 http://ecer-org.eu/about/, last accessed February 26, 2014.

101 Cf. Gregorius, Modern Asatro, 86f. For a discussion of the disputed term 'ethnic' in this organization, initially known as the World Pagan Congress, see Strmiska, "Modern Paganism in World Cultures. Comparative Perspectives," 14f. He emphasizes that the concept of 'ethnic' in this context had nothing to do with "ethnic purity" or "race ideology," 
Asatruers, not least due to its early public condemnation of "discrimination, suppression, or persecution based on race, color, social class, religion, or national origin."102 It was seen as a good forum in which to further the legitimatization of one's own efforts toward public recognition. ${ }^{103}$ Throughout the first half of the 2000s, more groups joined, including the German Eldaring and the Norwegian Foreningen Forn Sed. ${ }^{104}$

Gradually though, more and more groups and individuals voiced a growing unease with the way the WCER was run, with its guiding principles, and with some of the groups involved. ${ }^{105}$ The problems came to the surface after the WCER's 2008 meeting, which was held at the castle of Rothenhorn in the village Jedrzychowice (formerly known under the German name Heyersdorf) in

but rather denoted "anything that defines a people: its language, customs, daily behavior, food...or spiritual outlook." (15) Conceptions of ethnicity in Asatru are discussed in Chapter 4.

102 Jonas Trinkunas, "Revival of the ancient Baltic religions. Presented at the First International Gathering and Conference of Elders of Ancient Traditions and Cultures in Mumbay, India. Presentation sponsored by the Infinity Foundation," Infinity Foundation, http://www.infinityfoundation.com/mandala/h_es/h_es_trink_j_baltic.htm, last accessed February 26, 2014, 6 .

103 Cf. Gregorius, Modern Asatro, 87.

104 The WCER's intensifying involvement with Hindu organizations, built on the idea of a common Indo-European religious heritage surviving in India, culminated in the participation of WCER-affiliated groups at the First International Conference and Gathering of the Elders in Mumbai (see Michael Strmiska, "Romuva Looks East. Indian Inspiration in Lithuanian Paganism," in Religious Diversity in Post-Soviet Society. Ethnographies of Catholic Hegemony and the New Pluralism in Lithuania, ed. Milda Alisauskiene and Ingo W. Schröder (Farnham/Burlington: Ashgate, 2012), 136-141; "Modern Paganism in World Cultures. Comparative Perspectives," 28), an event which was repeated in Jaipur in 2006 (cf. Carl Johann Rehbinder, "Multikulturell andlig konferens in Indien - en omtumlande resa på många sätt," Mimers Källa 13 (2006)) and in Nagpur in 2009 (See http://www indiastudychannel.com/resources/www.indiastudychannel.com/resources/49543-International-Conference-Gathering-Elders.aspx, last accessed February 26, 2014). Occasional criticism that this entailed contact with militant, radical Hindu nationalist groups did not attract significant attention from Asatru groups within the WCER. Gregorius, Modern Asatro, 87, mentions the participation of representatives for Vishva Hindu Parisad (VHP) a group known for its involvement in the riots leading to the destruction of the mosque of Babur in 1992. See also the justification in the Danish journal Valravn (Sarrinder P. Attri, "Striden om et tempel - historien bag AYODHYA," Valravn. Hedensk tidskrift om samfund og kultur 1 (2002)).

105 Icelander Hilmar Örn Hilmarsson recounts that he "became deeply distrustful after viewing some material from the Greek and Italian members. When I hear a mention of Julius Evola I head for the hills..." Correspondence with Hilmar Örn Hilmarsson(Ásatrúarfélagið). 
Poland, a castle owned by the late Sigrun von Schlichting (Armanen-Orden and ANSE). ${ }^{106}$

In 2010, the WCER changed its name to European Congress of Ethnic Religions $(E C E R)$. Its new homepage features a passage where the organization now distances itself from Ariosophy as well:

By Ethnic Religion, we mean religion, spirituality, and cosmology that is firmly grounded in a particular people's traditions. In our view, this does not include modern occult or ariosophic theories/ideologies, nor syncretic neo-religions. ${ }^{107}$

The Ariosophic, occultist, and rune magic branch of Asatru has had a significant impact on the internationalization of the movement beyond the ECER as well. Although the Armanen-Orden in Germany has held a low profile publicly and acted more as a secret society, it had some influence on the young Stephen Flowers (alias Edred Thorsson), who attended Armanen gatherings in 1981/82. Thorsson writes that these visits left him harboring "feelings of esoteric respect," but also the sense that he and the Armanen-Orden had "different heritages, different destinies." Nevertheless, Thorsson brought Guido von List's and other Ariosophists' ideas and writings to the attention of an English-speaking audience. ${ }^{108}$ His Rune Gild presents itself as an "initiatory group dedicated toward the serious exploration of the esoteric and innermost levels of the Germanic tradition, as well as the greater IndoEuropean culture of which it is but a branch." 109 The Rune Gild represents an

106 This fact, and especially her presence, as well as that of some members of the ANSE and the Armanen-Orden, caused a heated discussion about the WCER's history and politics, especially within German Asatru. The Eldaring in particular was heavily criticized for sending a delegation. See http://www.asawiki.de/index.php?title=Benutzer_Diskussion: Robert_Nordlicht, last accessed February 26, 2014. Consequently, an Eldaring workgroup investigated further into the Armanen-Orden's, ANSE'S and GGG's membership in the $W C E R$ and tried to inform other European Asatru groups about the problems arising from being associated with the Ariosophic faction within the WCER. To the Eldaring's chagrin, this educational initiative failed; as a consequence, the Eldaring decided in 2009 to leave the WCER. Cf. Correspondence with Kurt Oertel (Eldaring), 2010.

107 http://ecer-org.eu/, last accessed February 26, 2014.

108 Edred, History of the Rune-Gild, III (The Reawakening of the Gild 1980-2005), 36f, Stephen Flowers and Michael Moynihan, The Secret King. The Myth and Reality of Nazi Occultism (Los Angeles: Feral House, 2007), Siegfried Adolf Kummer, Rune Magic, edited and translated by Edred Thorsson (Smithville, Tx: Runa Raven, 1993).

109 Michael Moynihan, "Wisdom for the Wolf-Age. A Conversation With Dr. Stephen Flowers," New Dawn Magazine 77, no. March-April (2003). 
international network of select Asatruers, which currently has contact addresses in the USA, England, Germany, Finland, and Australia. ${ }^{110}$ As the author of numerous publications on runes and "Germanic mysticism," and as the founder of a number of occultist and Heathen organizations, Stephen Flowers/Edred Thorsson has been one of the most active, outspoken and influential protagonists in the Asatru community in North America, if not worldwide. Having studied Germanic and Celtic philology, he received a Ph.D. from the University of Texas at Austin in 1984, with a dissertation on Runes and Magic: Magical Formulaic Elements in the Elder Tradition. ${ }^{111}$ In the mid-1980s, Thorsson started publishing more popular books on Runes and Germanic magic aimed at the occult book market. ${ }^{12}$ As Stephen Flowers, he continued to publish academic work ${ }^{113}$ as well as translations and investigations of German Ariosophists such as Guido von List and Siegfried Adolf Kummer. ${ }^{114}$ After having left university teaching, he founded the Woodharrow Institute ${ }^{115}$ to further impart his theories to an academically interested audience. In addition, he started his own publishing company and online bookstore, Runa Raven Press. ${ }^{116}$

Thorsson/Flowers was also a regular contributor to the journal Tyr, which the influential Rune Gild member Michael Moynihan edited together with Joshua Buckley. This journal brought ideas of German Germanic Neopaganism and the German Faith Movement to the English-speaking world (e.g., about Géza von Neményi, the Germanische Glaubensgemeinschaft, and Ludwig

110 http://www.rune-gild.org/contact/, last accessed February 26, 2014.

111 Stephen E. Flowers, Runes and Magic. Magical Formulaic Elements in the Older Runic Tradition (New York: Peter Lang, 1986).

112 For example Edred Thorsson, Futhark. A Handbook of Rune Magic (Wellingborough, Northamptonshire: Llewellyn, 1984), Runelore. A Handbook of Esoteric Runology (Wellingborough, Northamptonshire: Llewellyn, 1987), The Nine Doors of Midgard. A Curriculum of Rune-Work (Smithville, Tx: Runa Raven, 2003 [1991]).

113 Stephen Flowers, "Magic," in Medieval Scandinavia. An Encyclopedia, ed. Phillipp Pulsiano (New York/London: Garland Publishing, 1993).

114 Cf. Guido v. List, The Secret of the Runes, edited and translated by Stephen E. Flowers (Rochester, vт: Destiny Books, 1988); Kummer, Rune Magic.

115 http://www.woodharrow.com/, last accessed February 26, 2014.

116 Runa Raven Press is currently listed as a branch of the occultist Magus Books, http://www .magusbooks.com/category/RUNA-Raven, last accessed February 26, 2014. Thorsson/ Flowers, books and other titles from his Runa Raven Press are now distributed by the expanding Swedish-British publisher ArktosMedia of the New Right (www.arktos.com, see also Adam Carter, "Packaging Hate - the New Right Publishing Network," Online Article, Searchlight (2012), http://www.searchlightmagazine.com/archive/packaging -hate- $\% \mathrm{E} 2 \% 80 \% 93$-the-new-right-publishing-networks). 
Fahrenkrog). ${ }^{117}$ On the other hand, Tyr seems to be widely acknowledged as an intellectually ambitious project, and is read and distributed by a number of groups internationally. Thus, the $A F A$ recommends it, and even sells it on its website. Furthermore, Stephen McNallen revived the AFA's journal, The Runestone, in a similar yearbook format as Tyr and acknowledges Joshua Buckley's "advice and guidance."118 Daniel Junker, a member of the German ORD/VfgH, makes a strong positive reference to it in the ORD's journal, Ringhorn. ${ }^{119}$ The format of the German HeidnischesJahrbuch (Pagan Yearbook), which Junker co-edited and published for a number of years, is so close to Tyr's that a certain inspiration does not seem unlikely. ${ }^{120}$

Two other authors affiliated with The Troth have had significant international influence on the development of Asatru beliefs as well. One is Freya Aswynn, whose book Leaves of Yggdrasil (first published in 1990, then published again under the title Northern Mysteries and Magick in 2002), along

117 See Markus Wolff, "Ludwig Fahrenkrog and the Germanic Faith Community. Wodan Triumphant," Tyr. Myth - Culture - Tradition 2 (2003/04); and the article by Géza v. Neményi, "Rune Song or Magic Charms? An Investigation of the 'Hávamál," Tyr. MythCulture - Tradition 3 (2007), transl. by Markus Wolff.

118 http://www.runestone.org/index.php?option=com_hikashop\&ctrl=product\&task=show\& cid $=14 \&$ name $=$ the-runestone-journal-1\&Itemid $=557 \&$ category_pathway $=10$, last accessed February 26, 2014.

119 See Ringhorn 36, 12.

120 A possible direct connection between the Rune Gild and the editors of Heidnisches Jahrbuch can be traced as well. Edred Thorsson relates the visit of Thomas Karlsson, from the Swedish occult order Dragon Rouge, at the Gild-Moot in Schleswig in 2005 (cf. Edred, History of the Rune-Gild, III (The Reawakening of the Gild 1980-2005), 159). The co-editor of Heidnisches Jahrbuch, Holger Kliemannel, is the leader of this order's German section (cf. biography Holger Kliemannel in Heidnisches Jahrbuch 2008, 493). Kliemannel is also editor of the occult journal Shekinah, which published an interview with Thomas Karlsson by Thomas Lückewerth in its issue 5:2009. Lückewerth is a regular contributor to Heidnisches Jahrbuch, where he published an article on the German mythological and völkisch artist Hermann Hendrich (Thomas Lückewerth, "Hermann Hendrich - Mythenmaler und Tempelkünstler," Heidnisches Jahrbuch 1 (2006)). It is unlikely that it is a coincidence that a review of a book about this fairly obscure painter also appeared in Tyr (Markus Wolff, "Review of 'Hermann Hendrich: Leben und Werk' by Elke Rohling," Tyr. Myth - Culture - Tradition 1 (2002)). It thus does not seem too farfetched to assume at least a loose association between the editors and authors of Heidnisches Jahrbuch and the editors of Tyr, which may well have been facilitated at the mentioned Gild Moot, or through other contacts between Dragon Rouge and the Rune Gild. (For Dragon Rouge cf. Kennet Granholm, Embracing the Dark. The Magic Order of Dragon Rouge - Its Practice in Dark Magic and Meaning Making (Åbo: Åbo Akademi University Press, 2005)). 
with its German translation, ${ }^{121}$ have provided inspiration for many Asatruers worldwide. This is even truer for Stephan Grundy (alias Kveldulf Gundarsson), The Troth's academic specialist or "Warden of the Lore." Gundarsson/Grundy initially worked in close contact with Edred Thorsson in The Ring of Troth, but took a different path later on. He has published a number of seminal books on Asatru, ${ }^{122}$ as well as historical fantasy with Germanic themes. His novels treating the Nibelungen material were widely read in German Asatru circles as well. ${ }^{123}$

With the advent of the Internet, the connections within international Asatru intensified. Most of the bigger mailing lists have threads in English in addition to their respective native languages, and a number of international closed and open lists as well as online forums have formed. According to one of my German interview partners, current international Asatru contacts function analogously to the "Facebook principle," i.e. a snowballing system of more or less committed personal or online connections. The Scandinavian groups, which started in the mid to late 199os, have traditionally been in close contact with each other, which is facilitated by the similarities between the Norwegian, Danish and Swedish languages. Personal contacts and the existence of 'internet Heathens' enabled Germans interested in Asatru to find a forum for their interests outside of the Ariosophically-tainted German scene in the 199os.

In spite of such international cross influences, these are not always acknowledged by individual Asatruers. Scandinavian Heathens in particular tend to consider American Asatru as somewhat less authentic and more

121 Freya Aswynn, Leaves of Yggdrasil. Runes, Gods, Magic, Feminine Mysteries, and Folklore (St. Paul, MN: Llewellyn, 1990), Northern Mysteries and Magic. Runes and Feminine Powers (St. Paul, MN: Llewellyn, 2002), Die Blätter von Yggdrasil. Runen, Götter, Magie. Nordische Mythologie \& weibliche Mysterien, trans. Lionel Snell (Vienna: Edition Ananael, 1998).

122 Kveldulf Gundarsson, Teutonic Magic. The Magical and Spiritual Practices of the Germanic People (St. Paul, mn: Llewellyn, 1990); Teutonic Religion. Folk Beliefs \& Practices of the Northern Tradition (St. Paul, MN: Llewellyn, 1993); Our Troth; Kveldúlf Hagan Gundarsson, Wotan: The Road to Valhalla, E-book www.aswynn.co.uk (s.l., n.d.).

123 Stephan Grundy, Rhinegold (New York: Bantam, 1994); Attila's Treasure (New York: Bantam, 1996). For a more in-depth discussion of Grundy's literary work see Chapter 9. Grundy currently resides on a remote farmstead in Ireland leading a withdrawn life with his wife, but corresponding with Asatruers worldwide. He is also responsible for the two volumes of Our Troth, a comprehensive overview of the history and beliefs in Asatru, which is translated into German by Kurt Oertel, the "Warden of the Lore" of the German Eldaring. Cf. Gundarsson, Our Troth; Kveldúlf Hagan Gundarsson, Ásatrú. Die Rückkehr der Götter. Zusammengestellt von Kveldúlf Hagan Gundarsson. Deutsche Ausgabe erweitert und herausgegeben von Kurt Oertel (Rudolstadt: Edition Roter Drache, 2012). 
speculative, arguing that it is not tied to land and traditional culture in the same way as it is in those countries they themselves inhabit. An ethnicist Danish Asatruer, Søren Fisker, contradicts such reservations, invoking a paradigm of shared ancestry:

Even people who consider themselves so all-embracing universalist are somewhat narrow in their perception of what real Asatru is. And it obviously doesn't include the Americans. The fact that some emigrated to the USA apparently disqualifies them as Asatru. And personally I don't agree. I think they can be as much Asatru as we are even though their ancestors moved across half the globe. Realistically speaking, they have been going much longer than we in Denmark; they have been going since the eighties. So I actually think that they have been through many of the things twenty years ago that we are struggling with today. [...] And therefore I think that their experiences are also very relevant. ${ }^{124}$

As a consequence of such attitudes, Søren Fisker has been actively networking with international ethnicist Asatru groups over the past few years. In 2012, he was hosting the annual ECER congress in Denmark. ${ }^{125}$ Fisker was also involved in a controversy that was sparked off by an initiative that has become important for the intensifying network of European Asatru. In 2009, the first International Asatru Summer Camp (IASC) gathered around 150 members from nine Asatru associations in Denmark, Norway, Sweden, Germany, the Netherlands, Great Britain, and Spain; individual Asatruers from France and the U.s.A attended as well. The IASC featured blóts and rituals, lectures, workshops, and excursions, and was generally considered an important step in

124 Interview with Søren Fisker and Lars Irenessøn (Forn Siðr): "Selv folk, som skulle være sådan meget vidtfavnende universalistiske og så videre, de har en eller anden form for snæverhed i deres opfattelse af hvad der er rigtig asatro. Og den omfatter så tydeligvis ikke amerikanere. Det faktum, at der er nogle, der er udvandret til usA gør åbenbart, at de er diskvalificerede på forhånd som asatro. Og det er jeg så personligt ikke enig i. Jeg mener jo de kan være præcis lige så asatroende som vi er. Selvom deres forfædre er flyttet en halv jordklode rundt. Realistisk set har de jo været i gang væsentligt længere end vi har i Danmark. De har været i gang siden halvfjerdserne. Så jeg synes faktisk at mange af de ting, som vi sidder og døjer med, det er jo sådan lidt en øjneåber for mig, at det havde de jo siddet og døjet med for tyve år siden. [...] Og derfor synes jeg måske at deres erfaringer er også meget relevant for."

125 Cf. http://ecer-org.eu/event/program-for-the-15th-ecer-congress-odense-denmark/, last accessed February 28, 2014. 
forming an international Asatru community in Europe. ${ }^{126}$ In the lead up to the event, the invitation of outspokenly ethnicist groups and individuals, in particular the American AFA and the British Odinist Fellowship, caused considerable turmoil. The board of Danish Forn Siðr, which stood for the organization of the camp, had sent out invitations to both groups upon the initiative of two board members, Søren Fisker and Lars Irenessøn who, it later turned out, were members of the $A F A$ as well. ${ }^{127}$ The Norwegian Bifrost and the Swedish $S A S$ threatened to boycott the event, and then the two Dutch groups followed suit, perceiving the $A F A$ 's folkish approach as racist. ${ }^{128}$ The issue was eventually resolved, and the summer camp was on the whole considered an enormous success by all involved. In 2012, the camp was reprised, this time organized by the German Eldaring and $V f g H$, as well as the Dutch De negen verelden and Het Rad. ${ }^{129}$ Currently, Fisker and Irenessøn are building up a Danish branch of the $A F A^{130}$

The national and international controversies within Asatru are an indicator that a clear demarcation between a-racist Asatru and its ethnicist varieties is difficult to uphold. During the 1980s, there were attempts at actively concealing völkisch and racial themes within Germanic Neopaganism, especially in Germany. These have diminished considerably, not least due to an interaction between growing public awareness and media criticism on the one hand, and an equally increasing awareness of such problems within Asatru itself on the other. Asatru today is a politically diverse scene, ranging from leftist environmentalism to New Right ethno-pluralism. Many Asatruers are not involved

126 See e.g., the Post-IASC edition of the IASC Herald, an online newsletter created for the event (http://www.asatru-summercamp.eu/Docs/iasc_herald_2_print.pdf, last accessed February 28, 2014).

127 The following description is based on the documentation of the correspondences in Völse 47, March 2009, 40-52.

128 The origin of Bifrost's skepticism of McNallen and the AFA might lie in an event that took place in 2001. According to Asprem, "Heathens Up North," 62, Bifrost's head, Harald Eilertsen, published an article in $A F A$ 's magazine Runestone and was consequently "bombarded by letters and e-mails from enthusiastic American racialist Odinists." Eilertsen's urgent request to publish an article in which he could distance himself and Bifrost from any such racialist positions was never answered.

129 See http://www.asatru-summercamp.eu/, last accessed February 28, 2014.

130 See https://www.facebook.com/AsatruFolkAssemblyDenmark, last accessed March 10, 2014. For details see also the unpublished interview between Søren Fisker and Lars Irenessøn which, according to the author, was declined by the journal Vølse and published on the AFA Denmark's Facebook page: http://www.afa-europe.eu/docsys/docsys. php?tag=AFA\&docid=261, last accessed March 3, 2014. 
with and are in fact credibly appalled by völkisch, right-wing or racist ideologies. Hence, if we want to understand the controversies and difficulties inherent in drawing clear distinctions, we need to systematically discuss the history and various transformations of basic ideas, beliefs and practices within Asatru, rather than the more or less problematic activities of individuals, although the latter, no doubt, are of major significance as well. 